\title{
A Vector Error Correction Modeling of Security Spending and Economic Growth in Nigeria
}

\author{
Victor E. Oriavwote ${ }^{1}, \mathrm{PhD} \&$ Samuel J. Eshenake ${ }^{2}, \mathrm{PhD}$ \\ 1 Department of Economics and Development Studies, Faculty of Social Sciences and Humanities, Federal \\ University, Otuoke, P.M.B. 126, Yenagoa, Bayelsa State, Nigeria \\ ${ }^{2}$ Department of Economics, School of Arts and Social Sciences, College of Education, Warri, Delta State, Nigeria \\ Correspondence: Victor E. Oriavwote, PhD, Department of Economics and Development Studies, Faculty of Social \\ Sciences and Humanities, Federal University, Otuoke, P.M.B. 126, Yenagoa, Bayelsa State, Nigeria. Tel: \\ 234-080-3581-4123. E-mail: oriavwote40@yahoo.com
}

Received: March 25, 2013

Accepted: April 21, 2013

Online Published: April 26, 2013

doi:10.5430/afr.v2n2p59

URL: http://dx.doi.org/10.5430/afr.v2n2p59

\begin{abstract}
The study has been on the impact of security expenditure on the level of economic growth in Nigeria. Using data covering the period between 1980 and 2010, the ECM result shows that the expenditure on defence has a negative impact on the level of economic growth. An indication of flawed expenditure budgeting and implementation in the defence sector. Expenditure on internal security played important role in generating the desired level of economic growth in Nigeria. The low elasticity indicates that the significance was below expectations. The result of the variance decomposition shows that the shocks to expenditure on defense did not significantly explain the changes in the level of economic growth in Nigeria. Expenditure on internal security however played a role in influencing the level of economic growth in Nigeria. The result of the Johansen cointegration test shows a long run relationship among the variables and the error correction result shows a satisfactory speed of adjustment. It is thus recommended that government should reassess the content of her defense expenditure and make it more transparent and growth oriented.
\end{abstract}

Keywords: Defense Expenditure, Cointegration, Internal Security Expenditure, Variance, Decomposition and Economic Growth

\section{Introduction}

Security spending can be defined in terms of defense expenditure and internal security expenditure. Defense expenditure therefore refers to the quantity of society's resources that is allocated to the acquisition and management of military capability which are classified into recurrent and capital expenditures of the Armed Forces namely: Army. Navy and the Air Force. It involves the running expenses of the defense departments and other governmental agencies engaged in defense projects. Internal security has to do with the protection of the domestic territory and citizens by security agencies such as the police, civil defense, legal vigilante, prisons, e.t.c. Security spending is an important issue for the international economy. Security budget could be measured by the contributions of security to the Nigerian economy. Security budget include the payment of the salaries of armed forces personnel, thus enabling them to take care of their basic needs. The security budget also encompasses medical services, education and training of both local and foreign security personnel as well as research and development. The bulk of security expenditure is on the procurement of materials and equipments such as ammunitions of all categories. It is an expenditure by governments that has influence beyond the resources it takes up. Most countries need some level of security to deal with internal and external threats, but these can certainly have opportunity costs as they can prevent money being used for other purposes that might improve the pace of development. In recent times there has been increase in the expenditure on security in developing countries including Nigeria. This has drastically reduced funds for meeting the domestic development needs. Security expenditure accounts for one of the highest sectoral budgetary allocation in Nigeria in order to meet the growing security needs. Thus security expenditure not only competes with other public spending, but also affects the allocation of available resources. In the late 1970s and early 1980s, most developing countries of Africa including Nigeria experienced unprecedented economic slow-downs. This was manifested in several ways such as persistent macroeconomic imbalances, widening saving-investment gap, high rates of domestic inflation, chronic balance of payment problems and huge budget deficit (Akpokodje, 1998). Different reasons have 
been adduced for the slowdown of these economies. In Nigeria, for example, Akpokodje (1998), maintains that domestic investment as a ratio of Gross Domestic Product (GDP) declined from an average of 24.4 percent during the 1973-1981 period to 13.57 percent during 1982-1996 period. The billions of naira budgeted on security related spending in Nigeria has not been justified by the output from security. Due to the fact that investment determines the rate of accumulation of physical capital (otherwise called capital formation), it is then a vital factor in the growth of productive capacity of the nation and generally contributes to growth. It is in the light of this that prominence is being attached to increasing the magnitude of real asset investment in Nigeria. In particular, central to the less than satisfactory growth registered by countries of 57 sub-Saharan Africa, is low level of investment due to low domestic savings. Attracting foreign investment is therefore crucial from a number of standpoints and of course, there has never been shortage of theoretical arguments (Chete, 1998). However, one of the major challenges of any nation in attracting investment and hence economic growth is how to equip and maintain effective security forces that is capable of defending her against internal and external threats. The role of the Nigerian security forces is to promote economic activities through security and political stability. Conducive environment and investment climate can only be guaranteed through effective security network provided by the country's armed forces and other security agencies. The spillover of which is expected to lead to improved technology, manpower development, net increase in capital formation, and adequate infrastructure. However, it may, it has been observed in many countries, especially in Less Developed Countries (LDCs), that security expenditure consumes a large chunk of these nations' earnings (Dunne, Smith and Willenbocked 2005) Similarly, in the last two decades, the level of insecurity has assumed an alarming dimension ranging from political instability, to religious and social disturbances, bombing and kidnapping (Aiyedogbon, 2011). This situation made the country an unfriendly investment environment and thus, has scared away many investors especially foreigners and discourage yet many with intention to invest in the Nigeria's economy. This has hindered the level of economic progress. The objective of this paper therefore, is to investigate whether the spending on the security forces is commensurate with their contributions to economic progress by way of addressing the enormous security challenges. Other than this introductory section, the rest of the paper is divided into three sections. The second section is on literature review which encompasses both theoretical and empirical literature. The third section is on the econometric procedure and the fourth section conclude this paper.

\section{Literature review}

The introduction of new growth theories (Romer 1986, Lucas 1988) suggests that there exist both temporary effect from government intervention during the transition to equilibrium; and a possible long term effect from government spending on growth. This submission is against the thesis of neoclassical growth model as formulated by Solow which did not prescribe the channels through which government spending may influence long run economic growth. There are many ways that government activities can affect economic growth. The action may be beneficial and at the same time be detrimental. The positive side of government action can result in:

(i) The supply of pure public goods which may constitute a sizeable component of aggregate demand

(ii) The use of fiscal instrument like income taxes and transfer payments which can lead to more equitable redistribution of income

(iii) Government often acts as facilitator in the markets with asymmetric and imperfect information (Poot, 2000).

The action of the state may also impede economic growth. This is possible as a result of competition between the less efficient public sector and the private sector in the credit market which may jack up interest rate thereby dislocating private investment and eventually hampering economic growth. Taxes imposed by the state can equally distort market prices and effective resources allocation. Wagner's (1980) law suggested a different direction of causality between government spending and economic growth. Wagner argued that as the economy improves or expand, government spending tends to expand relative to national income. This thesis was built on the hypothesis that:

(i) Public functions can substitute for private activities

(ii) Government intervention is required to manage and finance natural monopolies

(iii) Expansion in the economy will lead to improvement in cultural and welfare expenditures

In summary, expanding state spending is seen as the product of economic development and not vice - versa.

The Keynesian effects of Wagner's law, present two opposite positions concerning the relationship between economic growth and government spending. While according to Keynes, causality runs from government spending to economic growth, Wagner law postulated that causality runs in the opposite direction. 
From the foregoing, security spending can be captured within the logic of explaining government spending. Security spending can have an adverse effect on economic growth through the crowding out of private investment. It may also distort resources allocation, and the diversion of resources from productive activities to the accumulation of armaments and the maintenance of sizeable security force. Security expenditure can equally affect the economy positively through an expansion of the aggregate demand (Keynesian effects). This will lead to increase in the utilization of idle capital, higher employment, profit and higher investment which will cause the economy to grow.

There have been growing empirical evidence on the impact of security spending and economic growth. However, the results that emerged have been mixed and subject to criticism due to the use of inappropriate empirical techniques. The neoclassical single supply side model of growth based on Feder (1982), Ram (1986) Biswas and Ram (1986) which is referred to as the Feder-Ram model has been used to analyze the effect of security expenditure on economic growth. The Keynesian demand side model derived from the Keynesian representation of aggregate demand and built on the initial work of Smith (1980) has also been adopted to analyze the relationship between security spending and economic progress. Another group consists of simultaneous equation model which incorporate the demand and supply sides to measure the impact of security expenditure on growth and is based on the work of Deger (1986), and is known as the Deger type model. However, there appears to be no clear agreement on the nature and extent to which the growth effects of security expenditure from there empirical studies.

Using the Feder-Ram model, Ram (1986), Atesoglu and Mueller (1990) found a positive impact while Biswas and Ram (1986), Alexander (1990) and Huang and Mintz (1991) concluded that there exists no relationship at all. With regard to the single demand side equation. Smith (1980) Fiani, Anne and Taylor (1984) and Raster and Thomson (1988) in their study on defence burdens, capital formation and economic growth showed a negative impact of defense spending on economic growth. Using one sample of 15 observations from each of the 57 countries, Joerding (1986) in a study on economic growth and defence spending used granger causality test and concluded that defence expenditure are not strongly exogenous and that it is reasonable to assume economic growth as an endogenous variable. He assumed a common time lag between the cause and the effect: and this might be different for different countries. By aggregating the samples, Joerding (1986) has assumed a common time lag structure for all countries in the sample. Olaniyi (1993) observed that the defense sector in Nigeria contributed positively for real growth of GDP and has a dampening effect on inflation rate. However, the impact was statistically low. Odusola (1996) who employed simultaneous equation model to estimate the relationship between military expenditure and economic growth in Nigeria found that aggregate military expenditure was negatively related to economic growth. He decomposed expenditure into recurrent and capital military expenditure and found that the former was more growth inhibiting than the latter. Dakurah, Davies and Sampath (2001) used cointegration and error correction model to study the causal relationship between the military burden and economic growth for 62 countries and found no common causal relationship between the military burden and economic growth among these countries. Seizgin (2001) studied Turkey's defence growth relationship. The study found that defence spending benefited growth. Galvin (2003) studied the impact of defence spending on economic growth. He used three equations, one each for growth, saving and defence expenditure. With the use of cross-sectional data for 64 countries, found using the OLS, 2SLS and 3SLS that military spending has a negative impact on economic growth. Ferda (2004) using new macro economic theory and multivariate cointegration procedure studied defense spending and economic growth in Turkey for the period 1950-2002 and found a positive long run relationship between aggregate defense spending and aggregate output in the country. Hassan, Waheeduzzanan and Rahman (2003) in their study on defence expenditure and economic growth in the SARCC countries. Using data covering the period between 1980 and 1999 found a positive relationship between military expenditure and economic growth. Anyanwu (2011) investigated defence spending and economic growth in Nigeria. Using a Vector Error Correction model the study found that there is a positive relationship between military expenditure and economic growth in the long and short run.

This study however differs from the previous studies since it decompose security spending into components. This is significant because most of the previous studies focused on only defence expenditure. The study also covers a wider scope which included the pre-Structural Adjustment Programme (SAP) period and SAP era of contemporaneous changes. The study also employs modern econometric technique of cointegration with its implied error correction which has been used by only few studies

\section{Econometric Procedure}

The Vector Error Correction Model (VECM) was used for the analysis because it restricts the long run behaviour of the endogeneous variables to converge to their cointegrating relationships while allowing for a short run adjustment (Gujaratti, 2003). The VECM is of the form: 


$$
\Delta y_{t}=\alpha \beta^{\prime} y_{t-1}+\sum_{i=1}^{j=1} \Gamma_{j} \Delta y_{t-1}+\pi+\varsigma_{t} t=\mathbf{1}_{s, \ldots,} T
$$

Where $y_{t}$ is a vector of endogenous variables which include Gross Domestic Product, expenditure on defence and expenditure on internal security. $\alpha$ s parameters measures the speed of adjustment through which the variables adjust to their long run values and the $\beta^{\prime}$ vectors are estimates of the long run cointegrating relationships among variables in the model. $\pi$ is the drift parameter and is the matrix of the parameters associated with the exogenous variables. The stochastic error term is also included in the specification.

The model to be estimated that would enable us analyze the impact of secuirty expenditure on economic growth in Nigeria is thus specified below:

LRGDP $=b_{0}+$ b1LEXINTSEC $+b_{2}$ LEXDEF $+e_{t}$

Where:

RGDP $=\quad$ Gross Domestic Product
EXINTSEC $=\quad$ Expenditure on internal security
EXDEF $=\quad$ Expenditure on defense
et $=\quad$ error term
$1 \quad=\quad$ Natural logarithm
R

\section{RGDP}

This is the Gross Domestic Product that has been deflated by the general price level

\section{EXINTSEC}

This is the money government spends in providing domestic security. It includes money spent on the police, National Civil defence Corp etc.

\section{EXDEF}

This is the expenditure by government on the defence of the territorial orders of Nigeria. Thus, it includes such expenditure as those on the army, navy, air force etc

The first step in the estimation process is the descriptive statistics. The result of the descriptive statistics is shown in table 1 below:

Table 1. Summary of Result of Descriptive Statistics

\begin{tabular}{lccc}
\hline & LRGDP & LEXINTSEC & LEXDEF \\
\hline Mean & 12.70687 & 11.03312 & 12.88097 \\
Median & 12.59047 & 10.75899 & 13.20719 \\
Maximum & 13.56550 & 13.96909 & 15.40276 \\
Minimum & 12.12031 & 7.425894 & 9.084709 \\
Std. Dev. & 0.442996 & 1.900670 & 1.809026 \\
Skewness & 0.532190 & 2.125088 & 1.660779 \\
Kurtosis & 2.642215 & 1.926453 & 2.718002 \\
& & & \\
Jarque-Bera & 2.477394 & 1.468237 & 2.206461 \\
Probability & 0.289761 & 0.479928 & 0.331797 \\
& & & \\
Sum & 368.4991 & 319.9605 & 373.5480 \\
Sum Sq. Dev. & 5.494875 & 101.1513 & 91.63206 \\
& & & \\
Observations & 29 & 29 & 29 \\
\hline
\end{tabular}


The skewness which is a measure of the asymmetry of the distribution of the series around its mean has values greater than 0 which indicates skewness to the right. The kurtosis which measures the peakedness or flatness of the distribution with an expected value of 3.0 shows that Real Gross Domestic Product and government expenditure on defense satisfy this condition. However, that of expenditure on internal security is platykurtic (less than 3 ). The Jarque-Bera test is used to test whether the random variables with unknown means and dispersion are normally distributed. The Jarque-bera test has the null hypothesis of normally distributed residuals. The probability value indicates an acceptance of the null hypothesis of normally distributed residuals. The next step is thus the unit root test.

The unit root test was used to test whether the variables are stationary and their order of integration. The Augmented Dickey Fuller (ADF) unit root test which corrects for higher order serial correlation is preferable to the Dickey Fuller (DF) test. The result is shown in table 2 below:

Table 2. Summary of ADF Unit root test result

\begin{tabular}{lllllll}
\hline Variables & Level Data & $1^{\text {st }}$ diff & $1 \% \mathrm{CV}$ & $5 \% \mathrm{CV}$ & $10 \% \mathrm{CV}$ & Order of Integration \\
\hline RGDP & 1.82 & $3.03^{*}$ & -2.63 & -2.98 & -3.61 & $\mathrm{I}(1)$ \\
EXINTSEC & 0.33 & $4.54^{*}$ & -2.63 & -2.98 & -3.61 & $\mathrm{I}(1)$ \\
EXDEF & -2.42 & $-5.31^{*}$ & -2.63 & -2.98 & -3.61 & $\mathrm{I}(1)$ \\
\hline
\end{tabular}

* Indicates statistical significance at the $1 \%$ percent level

The result of the ADF unit root test shows that all the variables were non stationary, but however became stationary after the first difference was taken. This pave the way to conduct the test of cointegration.

The cointegration test is used to test for the existence or not of a long run relationship among the variables. The Johansen methodology was preferable to the Engle- Granger since it is unbiased and allows for more than cointegrating equation. The result is shown in table 3 below:

Table 3. Summary of Johansen cointegration test result

\begin{tabular}{lccll}
\hline Hypothesized & & Trace & 5 Percent & 1 Percent \\
\hline No. of CE(s) & Eigenvalue & Statistic & Critical Value & Critical Value \\
None ** & 0.553898 & 37.33405 & 29.68 & 35.65 \\
At most $1 *$ & 0.395870 & 16.34662 & 15.41 & 20.04 \\
At most 2 & 0.117283 & 3.243507 & 3.76 & 6.65 \\
Hypothesized & & Max-Eigen & 5 Percent & 1 Percent \\
No. of CE(s) & Eigenvalue & Statistic & Critical Value & Critical Value \\
None * & 0.553898 & 20.98742 & 20.97 & 25.52 \\
At most 1 & 0.395870 & 13.10312 & 14.07 & 18.63 \\
At most 2 & 0.117283 & 3.243507 & 3.76 & 6.65 \\
\hline
\end{tabular}

The result in table 3 shows the existence of 2 cointegrating equations in the trace statistic and the max-eigen indicates one cointegration test. Thus, following Gujarrati (2003), the study concluded that there are 2 cointegrating equations since the trace test supersedes the max-eigen in case of conflicts. This is an indication of the existence of a long run relationship among the variables. The existence of at least 1 cointegrating equation permits us to estimate the error correction model. Which is shown in table 4 below: 
Table 4. Summary of ECM Result: Modeling RGDP

\begin{tabular}{lllll}
\hline Variables & Coefficients & Standard error & $\mathrm{t}$ values & probabilities \\
\hline LEXINTSEC & 0.067314 & 0.023692 & 2.841223 & 0.0088 \\
LEXDEF & -0.180739 & 0.038591 & -4.683402 & 0.0001 \\
LECM(-1) & 0.483866 & 0.105695 & 4.577960 & 0.0001 \\
C & 10.51295 & 0.214865 & 48.92817 & 0.0000 \\
\hline
\end{tabular}

$\mathrm{R}^{2}=0.86, \mathrm{~F}$ statistic $=70.47, \mathrm{DW}=2.05, \mathrm{~L}=$ Natural logarithm

The results show that expenditure on defence has a negative relationship with the level of economic growth in Nigeria. The low elasticity is also an indication that expenditure on defense has not generated the desired impact on the level of economic growth in Nigeria. Expenditure on internal security is statistically significant in influencing the level of economic growth. The result showed that an increase in the expenditure on internal security by 1 percent increased the level of economic growth by 7 percent. The negative and statistically significant ECM is an indication of a satisfactory speed of adjustment. It showed that about 48 percent of the errors are corrected each period.

The result of the Vector Error Correction (VEC) shown in table 5 suggests that the expenditure on defense constitutes the true cointegrating equation. The others are either not significant or have the wrong signs.

Table 5. Summary of VEC Result

\begin{tabular}{lccc}
\hline Cointegrating Eq: & CointEq1 & & \\
\hline LRGDP(-1) & 1.000000 & & \\
LEXINTSEC(-1) & -0.218495 & & \\
& $(0.01637)$ & & \\
& {$[-13.3490]$} & & \\
LEXDEF(-1) & 0.072562 & & \\
& $(0.01622)$ & & \\
& {$[4.47329]$} & & \\
C & -11.20862 & & \\
Error Correction: & D(LRGDP) & D(LEXINTSE & D(LEXDEF) \\
& & C) & $(1.18024)$ \\
CointEq1 & 0.020096 & -1.517651 & -420803 \\
& $(0.14558)$ & $(1.64756)$ & [-3.66095] \\
\hline
\end{tabular}

The result of the variance decomposition is shown in table6 below: 
Table 6. Results of Cholesky Variance Decomposition

Variance Decomposition of LRGDP:

S.E. LRGDP LEXINTSEC LEXDEF

Period

\begin{tabular}{lllll}
\hline \hline 1 & 0.049736 & 100.0000 & 0.000000 & 0.000000 \\
2 & 0.083157 & 99.59129 & 0.390357 & 0.018357 \\
3 & 0.108703 & 99.34114 & 0.508726 & 0.150131 \\
4 & 0.130385 & 98.54914 & 1.261467 & 0.189394 \\
5 & 0.150113 & 96.94740 & 2.898820 & 0.153776 \\
6 & 0.167998 & 94.19759 & 5.679636 & 0.122778 \\
7 & 0.184346 & 90.64167 & 9.249277 & 0.109056 \\
8 & 0.199832 & 86.44473 & 13.43251 & 0.122759 \\
9 & 0.214944 & 81.68270 & 18.15050 & 0.166800 \\
10 & 0.229940 & 76.55794 & 23.20365 & 0.238414 \\
\hline \hline
\end{tabular}

Variance Decomposition of LEXINTSEC:

S.E. LRGDP LEXINTSEC LEXDEF

Period

\begin{tabular}{lllll}
\hline \hline 1 & 0.562888 & 2.662441 & 97.33756 & 0.000000 \\
2 & 0.949313 & 2.679271 & 97.10905 & 0.211680 \\
3 & 1.338458 & 2.606634 & 96.59274 & 0.800623 \\
4 & 1.775313 & 3.319822 & 95.55938 & 1.120797 \\
5 & 2.230548 & 4.492130 & 94.17511 & 1.332756 \\
6 & 2.701393 & 5.641168 & 92.80193 & 1.556900 \\
7 & 3.192825 & 6.729659 & 91.51792 & 1.752420 \\
8 & 3.699624 & 7.774041 & 90.31382 & 1.912137 \\
9 & 4.216999 & 8.739005 & 89.20957 & 2.051424 \\
10 & 4.743122 & 9.613841 & 88.21292 & 2.173238 \\
\hline \hline
\end{tabular}

Variance Decomposition of LEXDEF:

S.E. LRGDP LEXINTSEC LEXDEF

Period

\begin{tabular}{lllll}
\hline \hline 1 & 0.403227 & 9.485201 & 16.52088 & 73.99392 \\
2 & 0.557625 & 15.88262 & 24.65912 & 59.45826 \\
3 & 0.777637 & 21.73192 & 45.10295 & 33.16513 \\
4 & 1.402692 & 21.94540 & 67.72713 & 10.32747 \\
5 & 2.197736 & 22.00201 & 73.70459 & 4.293408 \\
6 & 3.140160 & 21.78762 & 75.75545 & 2.456934 \\
7 & 4.201056 & 21.96851 & 76.18032 & 1.851173 \\
8 & 5.340348 & 22.36409 & 75.95045 & 1.685463 \\
9 & 6.540889 & 22.76186 & 75.54661 & 1.691526 \\
10 & 7.791559 & 23.13836 & 75.10350 & 1.758148 \\
\hline \hline \multicolumn{5}{l}{ Cholesky Ordering: LRGDP LEXINTSEC LEXDEF } \\
\hline \hline
\end{tabular}


The result indicates that the expenditure on defense did not explain significant portion of the changes in economic growth. The same is not true for expenditure on internal Security which explains about 18 percent in the $9^{\text {th }}$ period and 23 percent in the 10 th period.

\section{Conclusions and Recommendations}

This study is on the empirical investigation of the relationship between security spending (i.e defence expenditure and internal security expenditure) and economic growth in Nigeria using vector error correction model (VECM). Using annual data covering the period between 1982 and 2010, a unit root test (Augmented Dickey- Fuller Test) and a co-integration test (Johansen cointegration test) were carried out. The data were stationary after the first difference [i.e I (1)]. The Johansen test showed the existence of two cointegration equations using the trace statistics. From the ECM result, defence expenditure is negatively related to economic growth but with low elasticity. Expenditure on internal security is statistically significant in influencing changes in the level of economic growth. The result of the variance decomposition indicates that the expenditure on defence did not explain significant proportion of changes in economic growth whereas expenditure on internal security explains about 18 percent in the $9^{\text {th }}$ period and 23 percent in the $10^{\text {th }}$ period. That is, the contributions of the military at the moment through the security they offered have not had appreciable impact on real gross domestic product in Nigeria, as revealed in the variance decomposition test.

It is recommended that government should reassess the content of her defence expenditure and make it more transparent and growth oriented. Also, it is suggested that a policy of increasing the defence budget to promote economic growth might be inappropriate.

\section{References}

Aiyedogbon, J.O. (2011). "Defence expenditure and economic growth in Nigeria: A vector correction model (VECM) approach". Being a seminar paper presented at the Faculty of Arts \& Social Sciences, Nigerian Defence Academy, Kaduna. April, 14. (unpublished).

Akpokodje, G. (1998). "Macroeconomic policies and private investment in Nigeria", In: Rekindling Investment for Economic Development in Nigeria Ben. B. Aigbokhan (ed). Selected papers for the 1998 Annual Conference of the Nigerian Economic Society (NES).

Alexander, W.R.J. (1990). "The impact of defence spending on economic growth: A multi- Sectoral approach to defence spending and economic growth with evidence from developed economies". Defence Economics 2(1), 39-55. http://dx.doi.org/10.1080/10430719008404677

Anyanwu, S. (2011). "Defence expenditure and economic growth in Nigeria: A Vector Error Correction Model (VECM) approach". Asia Journal of Empirical Research. 1(2).

Atesoglu, H.S \& Muller, M.J. (1990). "Defence spending and economic growth". Defence Economics 2(1), 89-100. http://dx.doi.org/10.1080/10430719008404675

Benoit, B. (1973). Defence and Growth in Developing Countries. London Boston DC Heath; Lexington Books.

Biswas, R \& R. I Ram. (1986). "Military expenditure and economic growth in LDC: An augmented model and further evidence" Economic Development and Cultural Change 34(2), 361-370. http://dx.doi.org/10.1086/451533

Chete L.M. (1998). "Determinants of foreign direct investment in Nigeria". SER Monograph Series, 7, 89-336.

Dakurah H; Davies, S. \& Sampath, R (2001). "Defence spending and economic growth in developing countries: A causality analysis" Journal of Policy Modeling 23 (6) 651-658. http://dx.doi.org/10.1016/S0161-8938(01)00079-5

Deger. S. (1986). "Economic development and defence expenditure" Economic Development and Cultural Change 34(2), 361-372.

Dunne, J.P, Smith, R.P \& Willenbocked, D. (2005). "Model of military expenditure and growth: A critical review" Defence and Peace Economics 16(6), 449-461. http://dx.doi.org/10.1080/10242690500167791

Eralp, D.U \& Beriker, N. (2005). "Assessing the conflict resolution potential of the E.U: The conflict and accession negotiations "Security Dialogue" 36, 175-192. http://dx.doi.org/10.1177/0967010605054647

Feder, G. (1982). "On exports and economic growth" Journal of Development"12(1-2), 59-73.

Ferda, H. (2004). "Defence spending and economic growth in Turkey: An empirical application of new macroeconomic theory." Review of Middle East Economic and Finance, 2 (3), 193-20. 
Fiani R; Anne, P. \& Taylor, L. (1984). "Defence spending and economic growth: Time series evidence on causality for the Philippines 1950-1982" Journal of Philippine Development 25,(2), 354-360.

Galvin, H. (2003). "The impact of defence spending on the economic growth of developing countries: A cross section study", Defence and Peace, 14(1), 51-59. http://dx.doi.org/10.1080/10242690302932

Gujarati, D. N. (2003). Basic Econometrics (4e). New York: McGraw-Hill Inc.

Hassan, Waheeduzzanan \& Rahman. (2003). "Defence expenditure and economic growth in the SARCC countries. The Journal of Political, Social and Economic Studies" 28(3), 275-293.

Huang, C. \& Mintz, A. (1991). "Defence expenditure and economic growth: The externality effect. Defence Economics 3 (2), 35-40. http://dx.doi.org/10.1080/10430719108404713

Jeffery, K and Edward, K. (2008). "Bringing the military back in military expenditure and economic growth 1990-2003". Journal of World system Research xiv(2), 142-172.

Joerding, W. (1986). "Economic growth and defence spending: granger causality" Journal of Development Economics 1, 35-40. http://dx.doi.org/10.1016/0304-3878(86)90037-4

Lucas, R.E. (1988). "On the mechanics of economic development." Journal of Monetary Economics 22(1), 3-42. http://dx.doi.org/10.1016/0304-3932(88)90168-7

Mehan, R.A. (2004). "An econometric contribution to the U.S defence growth nexus: evidence from error correction model". Conflict Management and Peace Science 21 121-131. http://dx.doi.org/10.1080/07388940490463906

Odusola, F.A. (1990). "Military expenditure and economic growth in Nigeria". Nigeria Journal of Economic and Social Studies 38(1).

Olaniyi, O. (1993). "Nigeria nation defence and economic development: An impact analysis". Scandinavian Journal of Development Alternative Xll (2-3).

Poot, J. (2000). "A synthesis of empirical research on the impact of government on long run growth". Growth and Change 31, 516-546. http://dx.doi.org/10.1111/0017-4815.00143

Ram, R. (1986). "Government size and economic growth: A new framework and some evidence from cross-section and time series data" America economic review 76(1), 191-203.

Raster, K \& Thompson, W.R. (1998). "Defence burdens, capital formation and economic growth". Journal of Conflict Resolution 32(1), 61-86.

Reitschnller, G \& Loeming, J.L. (2005). "Modeling the defence growth nexus in Guatemala". World Development 33(3), 513-521. http://dx.doi.org/10.1016/j.worlddev.2004.08.008

Romer, P.M. (1986). "Increasing return and long run growth" Journal of Political Economy 94(5), 1002-1037. http://dx.doi.org/10.1086/261420

Rufael, W.Y. (2001). " Causality between defence spending and economic growth, the case of Mainland China: A comment". Journal of Economic Studies 28(3), 227-230. http://dx.doi.org/10.1108/EUM0000000005471

Serzign, S. (2001). "An empirical analysis of Turkey's defence-growth relationship with a multi-equation model (1956-1994)". Defence and Peace Economics, 12(1), 69- 81. http://dx.doi.org/10.1080/10430710108404977

Smith, R. (1980). "Military expenditure and investment in OECD countries 1954-1973" Journal of Comparative Economics 4(1), 11-32. http://dx.doi.org/10.1016/0147-5967(80)90050-5

Solow R.M. (1950). "A contribution to the theory of economic growth", Quarterly Journal of Economics, 70(1), 65-94. http://dx.doi.org/10.2307/1884513

Wagner, A. (1890). Finanzwissens chaft (3ed) partly Reprinted in Musgrave, and Peacock, A.T (ed.) The Classics in the Theory of Public Finance. Macmillan, London 1958. 

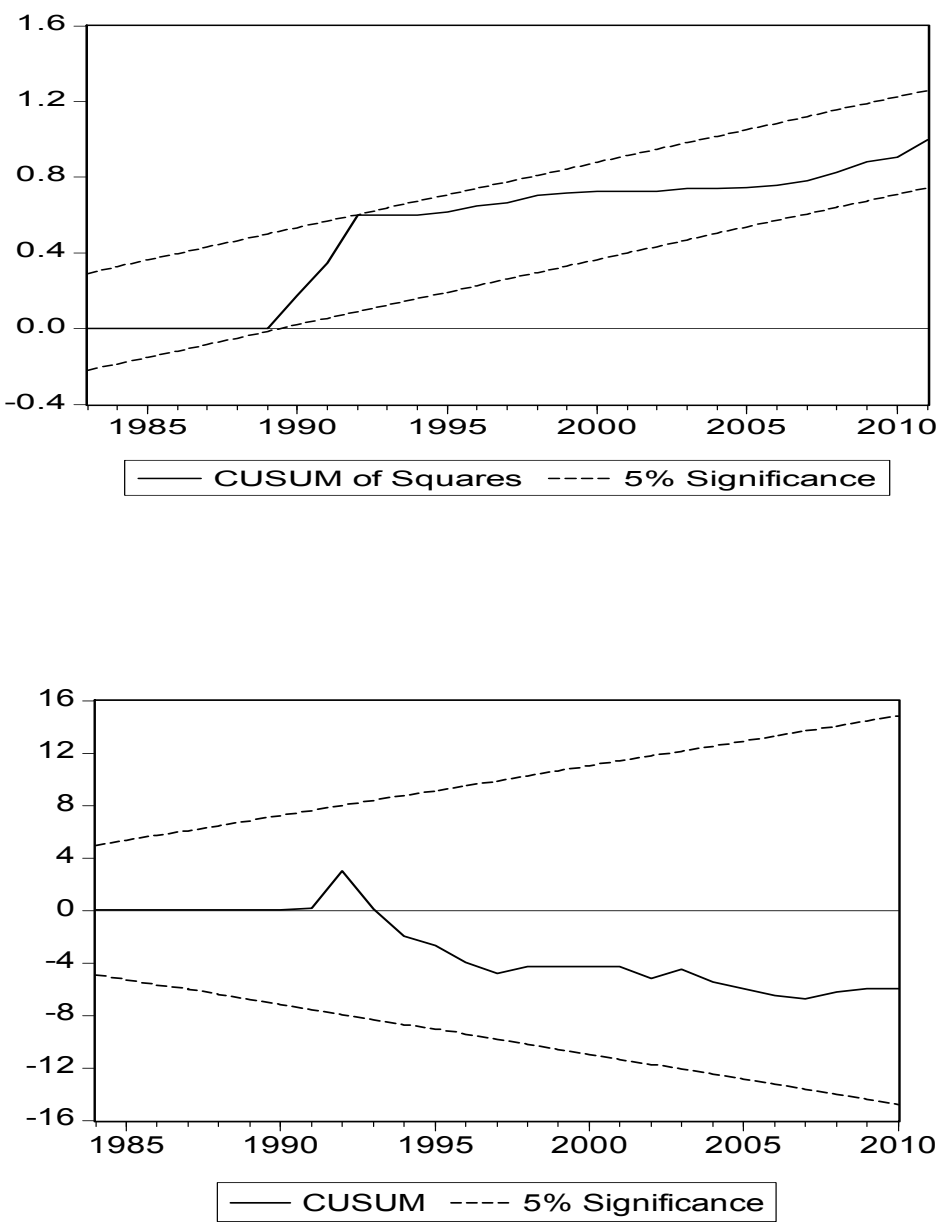